\title{
ANALYSIS OF POLYGAMY PROVISION UNDER THE ISLAMIC FAMILY LAW (FEDERAL TERRITORIES) ACT 1984 WITH REFERRENCE TO THE QUR'ĀN AND SUNNAH
}

\author{
Raudlotul Firdaus Binti Fatah Yasin*
}

\begin{abstract}
Islam permits polygamy to preserve woman's dignity and cares for the social moral and economic wellbeing of wives and orphans. Unfortunately, a number polygamous marriage among Muslims in Malaysia is dramatically misleading from both Islamic theories as well as principles. Hence, it has become a very controversial issue among its critics and supporters which resulting in serious criticism on the credibility of Islamic Family Law Act 1984.(ILLA) As a short term measure, a reform the IFLA has been suggested to focus more on specific legal mechanisms in curbing abuse of polygamy. In this paper the author attempts to analyze the synchronization of the IFLA in the light of Qur'an and Sunnah in order to suggest more effective, practical, and acceptable solutions in overcoming the issues and complying with the
\end{abstract}

* B.A. Hons in Usuluddin Tafsīr, (Al-Azhar University, Egypt), M.A. in Qur'an and Sunnah Studies, Islamic Revealed Knowledge (International Islamic University, Malaysia). The researcher is currently a $\mathrm{PhD}$ candidate and Part Time Lecturer in the same department, IIUM. 
requirements by 'following the real teaching in the revelation.'

Keywords: Polygamy, Provisions of Qur'ān and Sunnah, IFLA 1984, Polygamy applications, Darar shar'īe.

\section{INTRODUCTION}

Islam allows a man to marry more than one wife with certain regulations and restrictions. This permission is derived from the Qur'an, Sürah An-Nisā': 3. In certain circumstances, this permission proves tremendously useful and helpful, while some others, poses enormous challenges. ${ }^{1}$ When Islam permits polygamy, it preserves a woman's dignity and cares for the social moral and economic well-being of wives and orphans. Unfortunately, the nature of polygamy being widely practised among Muslims in Malaysia is dramatically misleading from both Islamic theories and practice.

Expectedly, the practice has generated serious criticisms on the credibility of Islamic Family Law Act 1984 (IFLA), which is enforceable by the Shari'ah Courts of each state in Malaysia. As a short term measure to overcome the problem, it has been suggested that IFLA should be reformed in order to address the current problems faced by Muslims. Therefore, the IFLA has been amended twice, in 1994 and 2005, and yet the Act has not been gazetted ${ }^{2}$ as some states have been objecting to the enforcement of the new enactment due to certain restricting provisions, which according to them is not in compliance with 'following the real teaching in the revelation.'

This paper seeks to examine the compatibility between the law of polygamy in the Islamic Family Law Act 1984 with reference to the Federal Territories as amended by Act A828 and A902, and the revelation

$1 \quad$ Particularly for those who might not be able to do justice among their wives, which may be injurious to society as a result of broken and uncoordinated marriages, which in turn produce illiterate, poor, and malnourished children.

2 Not presented and discussed in the Parliament at the time of writing this paper. 
of Allah in the Qur'an and the teaching of the Prophet in the sunnah. It analyzes the source, the relation, the efficiency and the suitability of the codification of the divine sources. The paper also makes suggestions and recommendations on how contemporary polygamy can be best practised in Malaysian society.

\section{AN OVERVIEW OF ISLAMIC FAMILY LAW PROVISIONS ON POLYGAMY}

Section 23 in Part II of the IFLA, which consists of eight sub sections generally focus on the administration, management of the application, registration, as well as general conditions of the proposed marriage in order to gain the Court's permission which is compulsory before the proposed marriage takes place. Meanwhile, the latest amendments of the IFLA that have been introduced under the Amendment of 2005 enable the first wife to claim her share of the matrimonial property upon her husband's polygamy. Another amendment requiring the man, his existing wife, his prospective wife and her guardian to appear before the court further protects women because it allows the judge to determine the suitability of the application.

Moreover, the existing condition of "just and necessary" under section 23 of the IFLA Act, 1984, is amended to "just or necessary" which means the husband is required only to prove the polygamous marriage is necessary, and need not prove that it is also just.

There is no sufficient information on fiqh and Shari ' ah elements in the codification to explain the source and conditions of polygamy marriage as highlighted in the Qur'an, Sürah An-Nisā': 3, as well as authentic traditions (ahädith). Furthermore, the stringent conditions, restrictions and punishments enshrined in the divine sources for those who are not qualified enough to practise polygamy or for those who treat their wives unjustly in a polygamous relationship are not included in the IFLA, which accordingly contributes to the misinterpretation of certain purposes of the divine law (maqașid al-Sharī'ah) relating to polygamy. 


\section{THE PERMISSION OF POLYGAMY}

In Islam, Men are allowed to take up to four women for wives. This permission of polygamy is sanctioned on the command of Allah as stated in the Qur'an, Sürah An-Nisā'? 3:

Meaning: "And if you fear that you shall not be able to deal justly with the orphan-girls, then marry (other) women of your choice, two or three or four; but if you fear that you shall not be able to deal justly (with them), then only one, or (the captives) that your right hands possess, that is nearer to prevent you from doing injustice."

A number of prophetic traditions that explain the reasons for the revelation of the verse has been recorded in detail. The most authentic narration on the reason for the revelation of this verse was stated by 'Aishah r.a. when she was asked by her nephew 'Urwah bin Zubair about this verse, she replied: "O my nephew! (This verse was revealed in connection with) an orphan girl under the guardianship of her guardian who was attracted by her wealth and beauty and intended to marry her with a Mahr (dowry) less than what other women of her calibre deserve. So they (such guardians) have been forbidden to marry them unless they do justice to them and give them their full Mahr, and they are ordered to marry other women instead of them." 3 They could only marry two, or three or four as the maximum, as unlimited polygamy was a normal practise at that time. Hence, this verse limited the permissible number of wives in a polygamous marriage. The purpose is very clear, to avoid any form of injustice towards the orphan girl.

In another narration as quoted by At-Tabari in his book: “...an orphan girl under the guardian of a man who was probably interested in her properties only, without desire in her, married her but offended her, indeed this verse was revealed to condemn his action..."4

3 Al-Bukhārī, Muḥammad bin Ismā'il. 2003 Șaḥ̄ḥ Al-Bukhārī (3rd edn.). Dār As-Salām, Riyadh, Kitab At-Tafsīr, no. 4574, at p. 376-377. Aț-Ṭabarī , Abī Ja’far. 2000 Jāmi ' Al-Bayān (1 ${ }^{\text {st }}$ edn.). Mu’assasah Ar-Risālah, Beirut, vol. 7, at p. 531. 
Diverse interpretations regarding this verse mentioned in traditional and modern Muslim exegetes (mufassirūn), fundamental hadith explanations and commentaries (Shurüh Al-Hadith), as well as classical juristic opinions lead to the overall conclusion that polygamy is a form of permissible and not mandatory practice, nor was it encouraged. This is based on the verse "but if you fear that you shall not be able to deal justly (with them), then (marry) only one” (Sürah An-Nisā': 3). This implies that Allah The Almighty ordered men who are not able to be just if they marry the orphan girls, to either marry other women and be fair to their wives, whether two, three or four, or else to never marry more than one wife in order to avoid any kind of oppression and injustice towards women. ${ }^{5}$

The lesson from this verse is that Allah did not make polygamy an essential practice in family building, as it is not mandatory for every man to practice it, and it is not an honour that must be present in every home. Allah has prescribed polygamy to protect women from the evils of greedy men who misused the practise of polygamy for their personal interests whether financial, lust or desire.

This source of revelation and interpretation is not stated or even slightly mentioned in the IFLA as an introduction to the polygamy provisions so as to give the general idea of divine origin of the revelation. This is important since most of the polygamous practises nowadays are not basically according to the spirit of the divine sources, or at least as pure as it is required to be, which unfortunately result in the abuse of wives and children. Indeed, a large number of men nowadays understand polygamy as 'the right of Muslim men sanctioned by Shari 'ah' rather than a sacred Shari 'ah provision that is aimed at realizing the real purposes of divine law as enshrined in the verse and authentic tradition.

See Az-Zuhailī, Wahbah. 1997 Al-Fiqh Al-Islāmī wa Adillatuhu (2nd edn.). Dār Al-Fikr, Beirut, vol. 9, at p. 6669; Az-Zuhailī, Wahbah. 1998 At-Tafsìr Al-Munīr (2 ${ }^{\text {nd }}$ edn.). Dār Al-Fikr, Beirut, vol. 4, at p. 234-235; Abū Shaqqah, 'Abdul Halīm Muhammad. 2002 Taḥrīr Al-Mar'ah fī 'Aṣri Ar-Risālah. Dārul Qalam, Kuweit \& Cairo, vol 5, at p. 291; AlKurdistānī, Mathnā Amīn. 2004 Harakāt Tahrīr Al-Mar'ah min AlMusāwah ila Al-Jundur; edited by Muhammad 'Imārah Dār Al-Qalam, Kuweit, at p. 391; Ar-Rifā' $\overline{1}$, Hāshim bin Hāmid. 1987 Al-Kalimāt fī Bayān Maḥāsin Ta addud Az-Zawjāt Maktabah At-Taw`iyyah AlIslāmiyyah, Cairo, at p. 20. 
In fact, in the IFLA codification, it is stated immediately under Part II, Marriage, section 23 (1) that;

(1) No man, during the subsistence of a marriage, shall, except with the prior permission in writing of the Court, contract another marriage with another woman nor shall such marriage contracted without such permission be registered under this Act:

Provided that the Court may if it is shown that such marriage is according to Hukum Syara' order it to be registered subject to section $123 .{ }^{6}$

This provision focuses on the importance of getting written permission from the court when a husband intends to contract a polygamous marriage, while his wife is still alive. Asking permission from the court is neither stated directly in the Qur'an nor in the authentic hadith but it fulfills the general purpose of the Divine Law (maqāsid ash-Shari 'yyah). This is applied as part of the process of fulfilling the condition of being 'just' in the verse; "but if you fear that you shall not be able to deal justly" (Sūrah An-Nisā': 3). Some traditional and modern scholars agree ${ }^{7}$ that it should be a judge ( $q \bar{a} \bar{d} \bar{i} /$ h $\bar{a} k i m$ ) who can determine the justice of the particular husband. The technical approaches and the process in the court may differ from one place to another, but the purpose is in line with the Qur'anic teaching. This is to ensure that only such men who are capable enough physically and financially, and can do justice between the existing and proposed wives will be given permission by the court.

Although the proviso to section 23(1) states 'that the Court may if it is shown that such marriage is according to Hukum Syara' order it to be registered subject to section $123,{ }^{8}$ the conditions and principles relating to Hukum Syara' is not clearly indicated in the enactment. Through the relevant cases recorded, the marriage is considered valid according to

$6 \quad$ Islamic Family Law (Federal Territories) Act 1984. 2007 International Law Book Services, Petaling Jaya, at p. 18.

7 Namely some jurists from all schools; Shafi 'yyah, Hanābilah, Hanafiyyah and Mãlikiyyah.

$8 \quad$ Ibid, at p. 18. 
Hukum Syara' when all the procedures are fulfilled. The main figure in the Court is a wali (guardian). If the wali himself conducts the marriage, then the marriage is valid. However, if a wali is wali hăkim, then, the Court will determine whether the wali hăkim is qualified or not.

In the matter of Zainal Abidin bin Mohamed, ${ }^{9}$ the Shariah High Court in Terengganu rejected Zainal Abidin's application to register a polygamous marriage solemnized in Narathiwat, Thailand. The wali hăkim was considered as unqualified by the Court, therefore, the marriage was invalid because it was not accordance with the principles of Hukum Syara'. Athough there are legal provisions for the registration of polygamous marriages that have been conducted without Court's consent, the Court undertakes a thorough examination of the background of the marriage before it is validated to allow its registration. ${ }^{10}$

However, in author's view, the term Hukum Syara' used in this codification is very general in concept and has a deeper meaning. Different interpretations and description may emerge from different judges or marriage registrars on determining whether such marriage is in line with the Hukum Syara', as it depends on the judge's consideration and decision upon examining the applications. Therefore, the author believes that, it is very important to highlight in detail the description of what the Hukum Syara' covers under polygamy cases and what are the issues not covered by it. This will be the foundation and guideline for the judge or registrar while deciding or considering polygamy applications, by not only limiting their assessment to financial and physical abilities, but to include some other conditions which shall be discussed later. The conditions prescribed by Hukum Syara' such as their taqwa, faith, attitude towards other Muslims, fulfillment of Allah's commands, ${ }^{11}$ capability of dealing justly with wives, which in the view of all scholars and jurists ${ }^{12}$ applies to

9 Raihanah Abdullah. 2006 Legal Mechanism in Curbing the Abuse of Polygamy Unpublished Ph.D dissertation, International Islamic University Malaysia, Kuala Lumpur, quoted from Jurnal Syariah 1999, vol. 7, no. 2, at 159 .

10 See Ibid, at 212-213.

11 This can be observed through his Friday prayers attendance, congregational prayers, honesty and responsibility in his working place and etc.

12 From the four schools of Shafi 'yyah, Hanäbilah, Hanafiyyah and Mãlikiyyah. 
housing, food, clothes, kind treatment ${ }^{13}$ and allotment of equitable time to each wife. ${ }^{14}$

\section{CONDITIONS OF POLYGAMY}

In order to achieve the court's permission to contract polygamy, there are certain conditions to be fulfilled by the applicant or husband, as provided in section 23 clause (3):

(3) An application for permission shall be submitted to the Court in the prescribed manner and shall be accompanied by a declaration stating the ground on which the proposed marriage is alleged to be just or necessary, the present of the applicant, particulars of his commitments and his ascertainable financial obligations liabilities, the number of his dependants, including persons who will be his dependants as a result of the proposed marriage, and whether the consent or views of the existing wife or wives on the proposed marriage have been obtained. ${ }^{15}$

Pursuant to this provision, the requirements to be fulfilled by the applicant who are as follows:

1. Proposed marriage is alleged to be just or necessary.

2. The presence of the applicant in the court.

3. Particulars of his financial commitments and liabilities.

13 See Taghārid Baydhūn. 1985 Al-Mar'ah wal Hayāh Al-Ijtimā'iyyah Dār An-Nahḍah Al-'Arabiyyah, Beirut, at p. 89-90; Badawi, Jamal Ahmad. 1987 Polygamy in Islamic Law American Trust Publications, London, at p. 3; Al-Maudūdī, Abū Al-A 'lā. 1985 Huqūq Az-Zawjah Ad-Dār As-Sa 'ūdiyyah, Jedda, at p. 41; Ar-Rifā'ī, Mahāasin Ta 'addud Az-Zawjāt, at p. 20; etc.

14 Al-'Imrānī, 'Abd Ar-Raḥmān. September 2009 Ta'addud Az-Zawjāt Matā Yuṣbih Mushkilah Ijtimā'iiyyah. Majallah Al-Wa yu Al-Islāmī, no. 527 Wizārah Al-Awqāf wa Ash-Shu'ūn Al-Islāmiyyah, Kuweit, at p. 2.

15 Islamic Family Law, at 18. 
4. Number of his existing and future dependants.

5. Whether consent of existing wife/wives has been obtained.

These requirements should be disclosed by the husband upon submitting his application for polygamy marriage. Failure to fulfill one of the conditions may cause rejection of the application. Generally, these requirements are meant to seek and investigate whether the proposal complies with the Hukum Syara'.

Subsequently, in Sürah An-Nisā': 3, Allah SWT states that the permission is stipulated upon completion of certain necessary conditions such as confidence of being just towards all wives. If a husband is not confident enough of being just or has a little doubt of his ability of being just, most scholars agree that he should remain with one wife and the permission is withdrawn ${ }^{16}$ under this injunction (Sürah An-Nisā': 3):

"But if you fear that you shall not be able to deal justly (with them), then (marry) only one, or (the captives) that your right hands possess, that is nearer to prevent you from doing injustice.”

In the light of the above, Prophet Muhammad (SAW) stresses that full justice including the previous aspects stated above should be done to all of the wives. It is reported by Abu Huraira in an authentic hadith that Prophet Muhammad SAW said:

"When a man has two wives and he is inclined to one of them (does not deal equitably between them), he will come on the Day of resurrection with an unbalanced gait." ${ }^{17}$

$16 \quad$ See Siddiqi, Muhammad Iqbal. n.d. The Family Laws of Islam Kazi Publication, Lahore, at p. 115; Aṭ-Ṭahtāwī, 'Alī Ahmad 'Abd Al- 'Āl. 2008 Al- 'Alāqāt Az-Zawjiyyah Dār Al-Kutub Al-'Ilmiyyah, Beirut, at p. 254; Al-Maudūdī, Ḥuqūq Az-Zawjah, at p. 41; Ar-Rifā'ì, Mahạasin Ta 'addud Az-Zawjāt, at p. 20; Baydhūn, Al-Mar'ah wal Hayāh AlIjtimā'iyyah, at p. 89-90; etc.

17 Narrated by Abu Hurairah, recorded by Abū Dāwūd. Sunan Abū Dāwūd Kitāb An-Nikāḥ, no. 2133, at p. 1380; An-Nasāi', Aḥmad bin Shu'aib bin 'Alī. 2000 Sunan An-Nasā'I (3rd edn.). Dār As-Salām, Riyadh, Kitāb An-Nikāh, no. 3394, at p. 2307. 
In order to investigate the applicant's possibility in fulfilling this requirement of being just, it is important for the husband to be present in court during the hearing of his application as stated in the section 23 clause (3). It is very crucial for the husband to provide his written financial particulars pertaining to the existing dependents and liabilities, so that the judge or registrar may analyze his capability on sponsoring another 'new' family resulting from the proposed marriage. Obviously, the IFLA codification on this matter is really following the Qur'an and sunnah provisions in a formal and systematic way.

Similarly the provisions in sub section (4) clause (b) and (c) requires the court to be satisfied with with the applicant's financial ability as well as equality of treatment to support both the existing and the future family before approving an application:

(b) that the applicant has such means as to enable him to support as required by Hukum Syara' all his wives and dependants as a result of the proposed marriage; (c) that the applicant would be able to accord equal treatment to all his wives as required by Hukum Syara'; ${ }^{18}$

This codification is in line with what is required in Sürah AnNisa $\bar{a}$ : 3, as Allah SWT highlights the condition of being just as the essential requirement in polygamous marriage, and in our modern situation, it is only the court that can ensure due process and judge the applicant's qualification through investigation and interview. If the court discovers that the applicant may somehow not be able to treat the wives equally due to his attitude and character, or unable to finance more than one family, then the court has all the grounds to disapprove the application. This is safer, not only for the welfare of the existing wife and children, but also in the husband's interest and advantage in this world and more importantly on the Day of Resurrection.

Although, it is 'incumbent upon every husband to do full justice to his wives in treatment and provision of economic sustenance, but he is helpless as far as natural inclination of his mind is concerned. ${ }^{19}$ After all, the justice required in the verse excludes the heart and its feelings

\footnotetext{
18 Islamic Family Law, at p. 19.

19 Muhammad Iqbāl, The Family Laws, at p. 116.
} 
which are beyond one's control. Allah SWT guided in another verse from the same Sürah:

Meaning: And you are never able to be fair and just as between women, even if it is your ardent desire: but turn not away (from a woman) altogether, so as to leave her (as it were) hanging (in the air). If you come to a friendly understanding, and practise self- restraint, Allah is Oft-forgiving, Most Merciful. ${ }^{20}$

Consequently, the Prophet (SAW) was recorded as praying to Allah asking for His forgiveness as he had tried his best to be just, but his heart is still not as just as his treatment towards his wives. ${ }^{21}$ He had also mentioned the glory and honor of a husband for his effort in struggling to be equal in treating and dealing with all wives; it was reported by 'Abdullah bin 'Amru in a tradition recorded by Bukhārī and Muslim that:

Meaning: Behold! The Dispensers of justice will be seated on the pulpits of light beside God, on the right side of the Merciful, Exalted and Glorious. Either side of the Being is the right side both being equally meritorious. (The Dispensers of justice are) those who do justice in their rules, in matters relating to their families and in all that they undertake to do. ${ }^{22}$

This tradition is Almighty Allah's praise towards His servant who is fair and exercises justice in ruling and discharging his responsibilities as a judge, a head of a family and a leader of his people and in whatever that is assigned to him. At the same time, Allah SWT acknowledges that

\footnotetext{
$20 \quad$ Sürah An-Nisā': 129.

21 Recorded by Abū Dāwūd, Sulaimān bin Ash'ath. n.d. Sunan Abū Dāwūd (edited by Muhammad Muhyiddīn) Dār Al-Fikr, Beirut, vol. 1, at p. 648; An-Nasāi', Sunan An-Nasā'i, Kitāb An-Nikāḥ, no. 3395, at p. 2307.

22 Recorded by An-Naisābūrī, Muslim bin Hujjāj. 2000 Saḥịh Muslim (3rd edn.) Dār As-Salām, Riyadh, Kitāb Al-Imārah, no.1827, at p. 10051006.
} 
perfect fairness and justice is very difficult and impossible in human capability. Therefore, the reward is very big and the appreciation is very honorable if they struggle to do so, as mentioned in this hadith. The Prophet (PBUH) himself in another hadith was recorded to highlight the obligation of fulfilling one's responsibility and that those responsibilities will be questioned on the Day of Resurrection:

Meaning: "All of you are guardians and responsible for your wards and the things under your care. The Imam (i.e. ruler) is the guardian of his subjects and is responsible for them and a man is the guardian of his family and is responsible for them. A woman is the guardian of her husband's house and is responsible for it." ${ }^{23}$

\section{CONSENT OR VIEW OF EXISTING WIVES}

Upon receiving the applicant's application to contract polygamous marriage, the provision provides that both parties should attend the proceeding:

(4) On receipt of the application, the Court shall summon the applicant and his existing wife or wives to be present at the hearing of the application, which shall be in camera, and the Court may grant the permission applied for if satisfied-

(a) that the proposed marriage is just or necessary, having regard to such circumstances as, among others, the following, that is to say, sterility, physical infirmity, physical unfitness for conjugal relations, willful avoidance of an order for restitution of conjugal rights, or insanity on the part of the existing wife or wives; ${ }^{24}$

23 Recorded by Bukhārī, Kitāb An-Nikāh, no. 5200, at p. 450. The hadìth repeated in other chapters several times such as Kitāb Al-Jumu'ah, Kitāb Al-Janāiz, Kitāb Al-'Itqu etc.

$24 \quad$ Islamic Family Law, at p. 19. 
In the Qur'an and sunnah, the wife's circumstances as stated in the provision is not directly stipulated. But the spirit of helping women is stipulated within the verse (Sürah An-Nisā': 3) that is to avoid injustice towards the orphan girls as well as women's interest in general. By looking at the wife's circumstances so stipulated, the majority of scholars agree $^{25}$ that it is the man's right to marry another woman who is much better rather than divorcing his existing wife. This is included as one of the 'wisdom of legitimacy of polygamy' as described by many modern Muslim scholars in their studies. ${ }^{26}$

Practicing polygamy is not associated with mere satisfaction of passion as most Malaysian men understood it nowadays; it is rather associated with compassion and responsibility towards unmarried women and widows. Upon entering polygamous marriage, one will definitely be questioned and evaluated in the hereafter of his responsibilities and fulfillment as mentioned in the hadith above.

The matter of obtaining consent of the existing wife to contract polygamy as provided in the secion 23 (3) is actually not included in the real framework of polygamy, nor anywhere stated in the Qur'an and sunnah. The only slightly related issue regarding 'obtaining idea' may be derived from the authentic hadith which reported that the Prophet (SAW) when he was asked if he would permit Saidina Ali r.a. to marry Abu Jahal's daughter, said that he would not. The hadith is as below:

See Az-Zuhailī, At-Tafsīr Al-Munīr, vol. 4, at p. 234-235; Al-Qāsimī, Muḥammad Jamāl Ad-Dīn. 1994 Maḥasin At-Ta’wil (edited by Muhammad Fuad 'Abdul Bāqī) Muassasah At-Tārikh Al-'Arabī, Beirut, vol. 2, at p. 217-219; Az-Zuhailī, Al-Fiqhul Islāmī, vol. 9, at p. 6669; Sayyid Qutb. 1996 Fĩ Dhilāl Al-Qur'an (2 ${ }^{\text {nd }}$ edn.). Dār AshShurūq, Cairo, vol. 1, at p. 579-581; Aș-Ṣabūnī, Muhammad 'Ali. 1999 Rawai 'Al-Bayān fī Tafsīr Āyāt Al-Aḥkām Dār Aṣ-Șabūnī, Cairo, vol. 1, at p. 302; 'Ulwān, 'Abdullah Nāṣiḥ. 1999 Ta'addud Az-Zawjāt fil Islām Dār As-Salām, Cairo, at p. 39-50; Mathnā, Harakāt Tahrīr AlMar'ah, at p. 391-396; Al-'Ațār, 'Abd An-Nāṣir Tawfīq. 1999 Ta'addud Az-Zawjāt min An-Nawāhi Ad-Diniyyah wal Ijtimā’iyyah wal Qanūniyyah Dār Asy-Syurūq, Jeddah, at p. 19-273; Taghārid Baydhūn, Al-Mar'ah wal Hayāh Al-Ijtimā'iyyah, at p. 85-100 and at p. 112-188; Abū Shaqqah, Tahrīir Al-Mar'ah, vol 5, at p. 291; Ar-Rifā' '̄', Maḥāsin Ta 'addud Az-Zawjāt, at p. 30; etc. Ibid. 
Meaning: From Miswar bin Makhramah reported that the messenger of Allah (PBUH) said while he was on the mimbar: "Verily, the relative of Banī Hāshim ibn Al-Mughìrah had asked me to marry their daughter with 'Alì Ibn Abì Tạlib, and I don't allow them, I don't allow them, I don't allow them, unless and until he divorces my daughter, for surely she is part of me and what troubles and agitates her, troubles and agitates me too; and what harm befalls her befalls me too."27

According to Ibn Hajar Al- 'Asqalānī, there is another prevention as explained in another longer hadīth narrated by Az-Zuhri that the Prophet (SAW) said “....I am not forbidding what is permitted, and I am not permitting what is forbidden, but Allah will never combine the daughter of Allah's messenger with the daughter of His enemy (Abu Jahal) at all." ${ }^{28}$ The time when the Prophet (SAW) delivered this speech on the mimbar was after he discovered that 'Ali was still determined on marrying Abu Jahal's daughter although he already prevented it before, while Fătimah as his wife was not aware of the matter at all. ${ }^{29}$ It should also be noted that marrying Abu Jahal's daughter was not legally prohibited, and was not the sole reason of the Prophet's dissension, but it was more to protect Fatimah's feeling and welfare. ${ }^{30}$ This concern is stated clearly in another narration by Sarī bin 'Aqlah, Ali was stated as consulting the Prophet (SAW) of his intention and the Prophet (SAW) answered:

Meaning: He (The Prophet (SAW) said: "No, Fatimah is part of me, I don't think except that she will be sad and hurt!", therefore Ali said: "I am not doing something she hates." 31

$27 \quad$ Recorded by Bukhārī, Saḥịh Bukhārī, Kitāb An-Nikāḥ, no. 5230, at p. 452; Ibn Mājah, Muḥammad bin Yazīd Al-Qazawaynī. 2000 Sunan Ibn Mājah (3rd edn.) Dār As-Salām, Riyadh, Bāb Al-Ghīrah, no.1999, at p. 2596.

28 Al-'Asqalānī, Ibn Hajar. 1996 Fatḥ Al-Bārī. (2 ${ }^{\text {nd }}$ edn.) Dār Al-Fikr, Beirut, vol. 10, Kitāb An-Nikāh, at p. 411-412.

29 Ibid.

30 See al-Nawawī, Yahyā bin Sharaf. 1392H Sharh An-Nawaw̄̄ 'Alā Muslim. (2 ${ }^{\text {nd }}$ edn.) Dār Iḥya’ Turāth Al-'Arabī, Beirut, vol. 16, at 2.

31 Al-Manāwī, Ittihāâf al-Sā’il bimā li Fāttimah min al-Manāqib, retrived from Maktabah al-Shāmilah, version 2007, 8. 
An alternative view proceeds on the basis that by that time the problem of orphans had already been solved, therefore the Prophet (SAW) prevented 'Alī from doing it. ${ }^{32}$

This event examined in the light of different narrations (riwayyah) can be understood in two ways; firstly, that the wife's consent or view is neither mandatory nor advocated in contracting polygamy, as Fätimah was not informed about 'Alï's plan until the Prophet (SAW) announced his disagreement during his speech in public. ${ }^{33}$

Secondly, it can also be understood from another narration recorded by Ibn Hibbān that her view and consent regarding the proposal was taken, it was quoted by Ibn Hajar in his book, that Fätimah was informed about the plan and she did not agree, ${ }^{34}$ she went to share her feelings with the Prophet (SAW) asking for his defense. ${ }^{35}$ Therefore the Prophet (SAW) stood up on the mimbar and delivered his message of strong disagreement.

The Prophet (SAW) himself in another hadith narrated by AzZuhri ${ }^{36}$ expressed his personal concern that Fätimah might be troubled with jealousy and deep sadness since the event took place after her mother passed away and her sisters died one after another, so, according to Imām Nawawì, she has nobody to console her other than her husband. ${ }^{37}$ When the Prophet (SAW) found out that his view was not taken into 'Ali's consideration ${ }^{38}$ and 'Ali was still insisting on marrying Abu Jahal's daughter, the Prophet (SAW) announced the matter in public. It can be understood here that if the wife's view is not required in such matters, then the Prophet (SAW) would not have interfered in his son in law's decision since a wife is under her husband's responsibility after her marriage.

32 Shehab, Rafiullah. 1986 Rights of Women in Islamic Shariah Indus Publishing House, Lahore, at p. 43.

33 According to narration of Az-Zuhrī, see Ibn Hajar, Fath Al-Bārī, vol. 10, at p. 411.

34 See Ibn Hajar, Fath Al-Bārī, vol. 10, at p. 412.

35 Narrated by Ibn Hibbān as quoted by Ibn Hajar in his book, see ibid. 36 Ibn Hajar, Fath Al-Bārī, vol. 10, Kitāb An-Nikāḥ, at p. 412.

37 Nawawī, Yahyā bin Sharaf. 1392H Sharh An-Nawawī 'Alā Muslim (2 ${ }^{\text {nd }}$ edn.) Dār Ihyya' Turāth Al-` Arabī, Beirut, vol. 16, at p. 2.

38 As understood from the tradition, see Ibn Hajar, Fath Al-Bārī, vol. 10, at p. 411-412. 
Judging by the current lifestyle and by looking at the reality of Muslim society in Malaysia, it would be a positive step forward to seek the wife's consent and view by both the husband and the Court prior to the conclusion of a polygamous marriage. There are many social and psychological reasons for letting the existing wife know about the proposal. The average Malaysian woman contributes substantially to the family institution, economically and financially ${ }^{39}$ in addition to be responsible for all the chores at home. Both parties should discuss the matter rationally with regards to their individual personal interests for the betterment of their family institution. Failure to inform the existing wife of the proposed marriage according to Dr Zaharuddin ${ }^{40}$ is also an early signal of the husband's failure to deal wisely in his future polygamous life. A real wise man can persuade his wife to accept his decision to marrying another woman without any need of cheating her. ${ }^{41}$ Furthermore, it has been concluded that 'the successful polygamous marriages are those where there is extensive communication between the husband and his existing wife.' ${ }^{42}$ Logically, 'the existing wife's experience of married life and cohabitation with her husband would provide information and assist the court in ascertaining the character of the husband and his ability or lack of it to contract another marriage. ${ }^{43}$

39 According to statistics, 46.4\% Malaysian females are employed, see Chart 1.1: Female Labour Force 2007. Retrieved on $6^{\text {th }}$ November 2009, from Ministry of Women, Family and Community website,http:// www.kpwkm.gov.my/new_index.php?page=statistic_content\& year=2008\&lang=eng.

$40 \quad$ He held many positions as Shariah Compliance and Advisor at RHB Islamic Bank, Asian Finance Bank, Standard Charted, OSK Investment Bank and Deutsche (Islamic) Bank. He was also a part time lecturer at European Institute of Human Science, Wales, UK. Currently he is a lecturer at International Islamic University Malaysia.

$41 \quad$ Zaharuddin Abdul Rahman. $3^{\text {rd }}$ November 2007. Poligami Secara Rahsia, OK? Retrieved on $9^{\text {th }}$ November 2009, from http:// www.zaharuddin.net/content/view/621/96/.

42 Soraya Khairuddin. 2008 Stemming The Tide: A Critique of The Reform of Polygamy Laws in Malaysia Unpublished M.A. dissertation, International Islamic University Malaysia, Kuala Lumpur, at p. 52. This fact is based on the researcher's interview with Prof. Dr Raihanah Abdullah, University Malaya, on 24 ${ }^{\text {th }}$ September 2007.

43 See Ramona Julia bt Abdullah v. Engku Nazrudin b. Engku Muhamed. 
Considering all these justifications, the role of the court is very crucial in deciding whether the proposed marriage is according to Hukum Syara' or not. It will be difficult to achieve happiness and justice in a polygamous marriage if the existing wife does not know, or worse than that, was not consulted at all, unless in very exceptional cases where the wife's consent may not be needed. ${ }^{44}$

\section{DARAR SHAR'IE}

Darar shar'ie as defined in IFLA means "harm, according to what is normally recognized by Islamic Law, affecting a wife in respect of religion, life, body, mind, moral or property." 45 In sunnah, darar shar 'ie is derived from a tradition, "Lā darar wa la dirārr," ${ }^{46}$ which means harmful or revengeful acts towards others, whereby it benefits the actor but harms others, or not even benefiting either of the parties at all. As such it has been prohibited. ${ }^{47}$

In accordance with this hadith, the court has to examine whether the proposed marriage will cause darar shar'ie to the existing wife. This is stipulated in section (4) clause $(d)$ :

(d) that the proposed marriage would not cause darar syarie to the existing wife or wives. ${ }^{48}$

(e) [Deleted].

$1999 \mathrm{JH}$ The importance of the wife's view or witness's evidence in polygamy application. Vol. xiii, part ii, at p. 215.

Such as the wife is abnormal, unconscious for a long period of time, paralysed etc. In these cases, the wife's view is not necessary especially if she will disagree, although her condition renders her religiously incapable of serving the husband according to Hukum Shara .

$45 \quad$ Islamic Family Law, at p. 8.

46 Recorded by Ibn Mājah, Sunan Ibn Mājah, Kitāb Al-Aḥkām, no. 2340, at p. 2617.

47 See Al 'Ainī, Badr Ad-Dīn. 2007 'Umdah Al-Qārī Sharh Saḥịh AlBukhārī Retrieved from Maktabah Shāmilah Software, version 2007, vol. 14, at p. 350.

$48 \quad$ Islamic Family Law, at p. 19. 
Analyzing this provision, again the matter of terminology should be discussed. The term darar shar 'ie is in the author's view, is very broad and contains many meanings. Further written explanation in the light of polygamy issues is better in order to provide the clear guideline to the judges, what can be regarded as "affecting a wife in respect of religion, life, body, mind, moral or property.” This will contribute somehow, to the uniformity in judging polygamy applications in all states.

In the light of Qur'an and sunnah, darar shar 'ie that may be caused by the husband upon entering polygamy marriage can be examined from the following points:

1. Affecting the wife's religion: This provision is related to the previous hadīth about 'Alì bin Abì Tălib and the daughter of $A b \bar{u}$ Jahal, whereby the Prophet (SAW) disagreed with the proposal because he was worried the marriage will affect her faith due to her uncontrolled jealousy where it might brought her to anger that is not suitable for her status. ${ }^{49}$ This was stated clearly in another narration by Az-Zuhrī:

“Meaning: I fear for her religious conviction”

2. Affecting the wife's life: The same hadith narrated as the Prophet (SAW) mentioned, “...for surely she is part of me and what troubles and agitates her, troubles and agitates me too; and what harm befalls her befalls me too." ${ }^{50}$

3. Affecting the wife's body.

4. Affecting the wife's mind: In a tradition narrated after the Hijrah event, it was recorded that a polygamous man from Anșāri offered one of his wife to be married with the Muhajirin and he was willing to divorce her. ${ }^{51}$ This event according to Ibn Hajar Al- 'Asqalāni was proof that it is permitted to avoid 'jealousy' between two wives ${ }^{52}$ (which affect their minds), to divorce her

\footnotetext{
49 Ibn Ḥajar, Fatḥ Al-Bārī, vol. 10, Kitāb An-Nikāh, at p. 412.

$50 \quad$ Ibid.

51 Recorded by Bukhārī, Sahih Bukhārī, Kitāb An-Nikāḥ, no. 5167, at p. 447.

52 Ibn Ḥajar, Fath Al-Bārī, vol. 10, at p. 295.
} 
and let her marry with other good man. The hadith stated before, according to Imām Nawawi is also another reason of how serious jealousy can be the reason to reject polygamy proposal. ${ }^{53}$

5. Affecting the wife's moral: In a hadith, the Prophet (SAW) described and praised the Quraish wives as "the kindest women to their children in their childhood and the more caring women of the property of their husbands." 54 Many Malay women have this positive attitude, but if the proposed polygamy will cause changes to the wife's behavior towards negative attitude, then polygamy in this situation not beneficial and can cause darar shar'ie.

6. Affecting the wife's property: Inability of a husband to conveniently finance a new family will definitely affect his existing wife's property and he is not entitled to do so. The Prophet (SAW) required 'financial ability of the man' as a prerequisite for marriage. In a famous hadith recorded by Muslim, he said to his male followers, "those among you who can support a wife should marry." ${ }^{5}$ It is understood that those who cannot support more than one wife, should not marry a second wife as this would be beyond his financial ability.

Any husband fails or intentionally refuses to act fairly commits darar shar'ie and harm on his wives. Doing harm to other Muslims is oppressing them, which is considered as a severe offence against Almighty Allah's law. A famous authentic hadith stating the prohibition of harming and oppressing brothers or sisters in Islam can be traced to a narration by 'Abdullah bin 'Umar that the Prophet (SAW) told him:

Meaning: "A Muslim is a brother of another Muslim, so he should not oppress him, nor should he hand him over to an oppressor." ${ }^{26}$

\footnotetext{
$53 \quad$ Nawawī, Sharh An-Nawawī, vol. 16, 2.

54 Recorded by Bukhārī, Sahih Bukhārī, Kitāb An-Nikāḥ, no. 5079, at p. 439.

55 Recorded by Muslim, Sahih Muslim, Kitab An-Nikāh, no. 1, at p. 910.

56 Recorded by Muslim, Sahih Muslim, Kitāb Al-Maẓālim, no. 32, at p. 32.
} 
Specifically, Allah SWT through His revelation has warned and at the same time reminded polygamous husbands from the very beginning to be just and fair at all times. Though perfect equality of love and passion is not possible yet, he must try his best to be just at all times. His failure to be equally fair in matters of finance, allotment of time, and sexual relation among his wives will result in harm and suffering (darar shar 'ie) which is deemed in the Qur'an as 'hanging in the air' (mu 'allaqah):

Meaning: And you are never able to be fair and just between women, Even if it is your ardent desire: but turn not away (from a woman) altogether, so as to leave her (as it were) hanging (in the air). ${ }^{57}$

Clause (5), (6) and (8) are mainly administration and management related process of polygamy that do not need analytical studies from Qur'an and sunnah perspective.

\section{PENALTIES}

If the applicant contravenes the procedures provided in section 23 (1), failing to gain written permission from the court to contract polygamy, yet he contracts it somewhere else or outside the region, ${ }^{58}$ he will be will be liable to the penalties provided in section 123:

Any man who, during the subsistence of a marriage, contracts another marriage in any place without the prior permission in writing of the Court commits an offence and shall be punished with a fine not exceeding one thousand ringgit or with imprisonment not exceeding six months or with both such fine and imprisonment. ${ }^{59}$

$57 \quad$ Sūrah An-Nisā': 129 . Mu 'allaqah according to At-Tabarī means 'a wife who is like neither having a husband (though she’s married), nor divorced (since her marriage still exists), see Aț-Ṭabarī, Al-Jāmi` AlBayān, vol. 5, at p. 367.

58 Such marriage is known in Malaysia as 'runaway marriage' where the applicant and the prospective wife contract their marriage outside the region, mostly at the Religious Affair in Southern Thailand. 
Looking at the trend of modern penalties, it is believed that this punishment is relatively low. 'The penalty has not served as a deterrent because until now, no husband has been imprisoned for contravening these rules. ${ }^{\prime 60}$ Referring back to the divine sources, there is no penalty for contracting polygamous marriage without the permission of the court or Syariah Judge. Instead, in Sürah An-Nisā'? 3, the very first consideration before any polygamous marriage takes place is the ability of the husband to deal justly between his wives, any single doubt in his capacity of being unjust after entering a polygamous marriage will be considered as a strong reason to prevent the husband from pursuing the intention of polygamy as mentioned before. No judge in any state or in the country at large is theoretically allowed to permit polygamy without investigating the husband's financial ability and religious background to ensure his potential in conducting himself as a just husband before granting the polygamy application

The spirit of the verse actually constitutes the husband himself as his own judge in the shoes of the Syariah Judge, inspecting his own possibility in handling another wife fairly and justly, or else ready to be punished by Allah SWT on the Day of Resurrection as earlier mentioned in the hadith. But in today's lifestyle lacking in faith and taqwā, it is extremely difficult to find a pious man who can rationally evaluate himself in which category he falls into, therefore, it has now become the judge's role to decide on the permission of contracting polygamous marriages. The consequences of any decision taken by the judge will be his responsibility towards the applicant, the existing and the prospective wife, as well as Almighty Allah . The judge bears a heavy burden, religiously and contextually, in carefully determining an applicant's right to have more than one wife. The Prophet, (SAW) in his tradition has emphasized on the important role of a judge and the punishment for being unfair in his judgment:

Meaning: Judges are of three (categories); two in the hellfire, one in the heaven, (firstly) a man who judges unfairly and he realizes that, shall be in the hellfire, (secondly) a judge who does not know while judging on Polygamy, 1996, Kuala Lumpur, at p. 5. 
and infringes other human's rights, shall be in the hellfire, (thirdly) the judge who decides justly, shall be in the heaven. ${ }^{61}$

Therefore, if a Syariah Judge unduly approves an unqualified applicant to contract polygamy, he will have to share part of the sins committed by the husband while being unfair or oppressive to the existing wife and children. Looking at this responsibility held by a Syariah Judge, the author would like to suggest here that the Syariah Judge in Malaysian Courts be given more authority in monitoring the polygamous families after the conclusion of polygamous unions. The Syariah Judge should have all the right to advise or warn (if necessary) the oppressive husband to improve his performance in dealing with all his wives justly. If the husband is still stubborn or unable to act justly, then he should be subjected to educative rehabilitation ${ }^{62}$ which may help to improve his family management skills.

According to the author's analysis, offences provided in section 123 of IFLA have no basis in either inthe Qur'an or the sunnah. More importantly, a stiffer penalty should be prescribed for those who fail to be fair intentionally in polygamous marriage. According to the divine sources, it is included in the right of the judge or Syariah Judge to inspect how the polygamous family registered under his supervision goes on. The Prophet (SAW) himself was recorded as inspecting the family life of his companions. It was narrated by Jäbir bin 'Abdullah that he was asked by the Prophet (SAW) about his progress with his wife and was given some advice by him. ${ }^{63}$ This event according to Ibn Battāl is a signal to a Syariah Judge to ask and to find out if the people need any help or advice regarding their family problems. ${ }^{64}$

61 Recorded by Abū Dāwūd, Sunan Abū Dāwūd, Kitāb Al-Aḥkām, no. 3573, at p. 1488.

62 Such as attending all five obligatory prayers congregationally in the mosques every day, participating in seminars and talks about Family in Islam gradually, or serving the nearby mosques or writing book reviews on the role of polygamous husband and etc. Recorded by Bukhārī, Șahih Bukhārī, Kitāb An-Nikāḥ, no. 5079, at p. 439. Shāmilah, version 2007, topic 7, vol. 13, at p. 165. 


\section{CONCLUSIONS AND RECOMMENDATIONS}

1. Through analytical studies of IFLA from the divine perspective enshrined in the Qur'an and sunnah, the author concludes that the provisions on polygamy in IFLA are mainly concerned to restrict the permission of polygamous marriage and limiting it to exceptional cases as highlighted in Sürah An-Nisā': 3.

2. The spirit of the polygamy provision in IFLA is in line with the divine purpose (maqāsid as-sharī'ah) to protect the orphan girls, wives and children, against darār shar ie caused by the irresponsible husband's abuse, but that spirit has not been clearly and properly addressed as it should have been.

3. Some terminologies used are very general and may lead to diverse interpretation on the real purpose. It is suggested that the terms such as hukum syara' and darār shar'ie should be defined in detail and clearer wordings to avoid disparities in judge's decisions in different states.

4. Although there are no direct divine sources on obtaining the existing wife's consent or views in contracting polygamy as imposed by the IFLA, the views of the existing wife is extremely relevant as this would provide more information to the court regarding husband's attitude and his financial condition as well as his sexual ability in order to "dispel much of the misery and injustice that is often encountered in polygamous marriage"65 within the Malaysian context.

5. Syariah Judges should be given more authority in handling and monitoring problems encountered in post polygamous marriages, so as to stop any form of darär shar 'ie from affecting the wife's religion, mind, body, moral and property. The Prophet (SAW) Protection of the Human Dignity of Muslim Women in Malaysia with Reference to Polygamy and Divorce Unpublished Ph.D. dissertation, International Islamic University Malaysia, Kuala Lumpur, at p. 364. 
himself used to ask the companions about the progress of their families, as mentioned in hadìth Jābir bin 'Abdullah.

6. It is allowed for a Syariah Judge to disapprove polygamy proposal if it will cause serious jealousy that may affect the wife's religion and moral as stated in hadīth about 'Ali, Fātimah and Abü Jahal's daughter.

7. An educative rehabilitation or penalties are highly encouraged to be introduced to check an oppressive husband, as in Islam, oppressing other Muslims is a serious offence against Almighty Allah's law as related in the hadith. 